\title{
Evaluating pharmaceutical marketing knowledge and attitude among medical representative in Mumbai City: A quantitative study
}

\author{
Virendra Ligade*, Juilee Bhegade \\ Department of Pharmacy Management, Manipal College of Pharmaceutical Sciences, Manipal Academy of Higher Education, Manipal, India.
}

\section{ARTICLE INFO \\ Received on: $11 / 05 / 2019$ \\ Accepted on: 31/10/2019 \\ Available online: 03/01/2020}

\section{Key words:}

Pharmaceutical marketing, medical representative, India, promotion, customer.

\begin{abstract}
Medical representatives are important members of pharmaceutical companies. They are hired based on some specific criteria like basic knowledge about clinical, pharmaceutical marketing, and selling skills which are suitable to interact with healthcare providers. They provide drug's information to healthcare professionals and help pharmaceutical companies to generate the sales. After hiring for medical representative, companies provide training on many aspects. Along with scientific research knowledge, they often need to be updated and well versed with pharmaceutical marketing knowledge. For success of any medical representative, sound knowledge of pharmaceutical marketing is necessary. Knowledge and attitude regarding pharmaceutical marketing need to be ascertained by medical representative from time to time. Evaluation about the same was the main focus of this study. This was an exploratory study that involved both primary research with the help of research survey and secondary research. Target sample was medical representatives working in various pharmaceutical companies. From the above survey, majority of the medical representatives felt that basics of pharmaceutical marketing knowledge are necessary for successful detailing and that will help them to increase sales. Adding to this, they also mentioned that they were only trained on how to read out the matter to healthcare professionals. Moreover, there are many basic pharmaceutical marketing concepts which are needed for better understanding and successful detailing.
\end{abstract}

\section{INTRODUCTION}

Sales representative in pharmaceutical marketing is called a medical representative. Pharmaceutical sales representative/medical representative has to perform crucial tasks in pharmaceutical marketing (Subba Rao, 1998). A medical representative is a vital link between the company and the medical professionals, distributors, and retailers. A genuine feedback is given by medical representative to the company on what is happening to the company's products in the market place in terms of its performance. They are involved in promotional activities. Promotion is a process utilized to tell the customers about product, place, and price. Promotion helps to provide information about the product and to convince potential customers (Impact of drug

"Corresponding Author

Virendra Ligade, Department of Pharmacy Management, Manipal College of Pharmaceutical Sciences, Manipal Academy of Higher Education, Manipal,India.E-mail: virendra.sl@manipal.edu promotion on doctors, 2011). As we go back to the history of pharmaceutical marketing, it reveals that the first pharmaceutical sales representative appears on the scene in the 1850 s in the United States (The Drug Rep: Historical Background, 2007). Unfortunately, there is no solid evidence to show when and how the pharmaceutical sales representatives appeared in the Indian pharmaceutical market. As medical representatives interact with healthcare professional regularly, they are expected to have current knowledge about the particular product and disease area and about all research related to the company product. They have to understand in-depth the information and clinical trials they detail and should be in a position to respond to concerns raised by healthcare professionals with regard to the results of the study. Pharmaceutical companies provide their medical representatives with a wide range of mandatory training for the continued operation of the business; however, these companies have often failed to offer research-related training (Mukattash et al., 2017). Along with scientific research knowledge, they often need to be updated and well versed with pharmaceutical marketing knowledge. For the success of any medical representative, sound knowledge of 
pharmaceutical marketing is necessary. If they are aware about the pharmaceutical marketing concept, they will be more confident and indirectly it will help their companies as well. Therefore, this study was carried out to evaluate the pharmaceutical marketing knowledge and attitude among medical representative in India.

\section{MATERIALS AND METHODS}

This was an observational study, which involved both primary research with the help of research survey and secondary research. Primary data were obtained with the help of a structured questionnaire. Secondary data were obtained from published literature in medical and management online and print journals, newspaper, magazines, opinion articles, and news items from the internet. Sampling technique used for the study was nonprobability convenience sampling. In nonprobability convenience sampling, population elements were decided at convenient time and place. The sample size is decided based on respondent's availability, in this method, the sample size is small and limited (Malhotra and Dash, 2010). Sample size used for the study was $(n=100)$. Research survey was carried out in Mumbai city, Maharashtra, India. The study was conducted between October 2018 and March 2019. The objective of the study was explained to the respondents. The study was approved at the Department level. Information obtained from respondents was held in strict confidence, hence names and other personal details were not asked for. Permission was sought from the respondents before being given the questionnaire. A questionnaire that consisted of a formalized set of questions was used for obtaining information from respondents. In the given questionnaire, openended and closed-ended questions were included. To assess the respondent's attitudes towards perception/attitude of medical representative towards basics of pharmaceutical marketing, a five-point Likert Scale (rating from $1=$ strongly disagree to $5=$ strongly agree) was utilized to measure the extent to which the medical representative agreed with statements related to attitudes and perception of medical representative regarding basics of pharmaceutical marketing subject. The questionnaire was divided into two sections addressing different topics. The first section deals with the attitudes and perception of medical representative regarding the basics of pharmaceutical marketing subject. Section two describes the understanding of medical representative to some basic pharmaceutical marketing terminologies/concept research terminologies. This section consisted of a total of 24 different pharmaceutical marketing terminologies/concept research terminologies.

Data analysis was carried out with the help of the data collected through questionnaires. The collected data were analyzed by the appropriate software like Microsoft Office Excel 2007. ChiSquare test was used to evaluate the difference between groups for categorical variables. For all statistical analysis, a $p$-value of $<$ 0.05 was considered as statistically significant.

\section{RESULTS AND DISCUSSION}

Table 1 explains about demographic information about respondents. $76 \%$ of respondents were male and $24 \%$ of respondents were female. $46 \%$ of respondents were B. Pharm, $23 \%$ were from B.Sc. background, 13\% from B.com stream, $5 \%$ from B.B.A, $4 \%$ from the M.B.A field, 3\% were MPharm, and others were $6 \%$.

$20 \%$ of respondents had experience of 1-2 years. Respondents having less than 1 year of experience were $18 \%$. Between 4 and 5 years of experience, there were around $17 \%$ of respondents.

Table 2 shows that $81 \%$ of medical representative strongly agree that there is a necessity of pharmaceutical marketing knowledge for successful detailing so as to increase sales volume. Majority $(72 \%)$ medical representative strongly agreed that there should be continuous training directed towards understanding concepts of pharmaceutical marketing strategies. So that they can implement these strategies to obtain maximum sales. $67 \%$ of medical representatives are of opinion that there should be continuous trainings directed toward marketing communication and selling skills. $64 \%$ of medical representative strongly agreed that there should be continuous trainings directed towards pharmaceutical product marketing and knowledge. Based on the above results and opinions, basic pharmaceutical marketing terminologies were asked to know whether they understand completely, somewhat, and did not understand anything about the concept.

From Table 3, it was noted that majority of the respondents were aware about the concept of prescribing behavior and understand it completely. It is very important for the medical representative to understand the prescribing habit of physicians towards particular drug or brand. Generating prescription is the main goal of all the respondents. Therefore, majority, i.e., 92\% of the respondents understands the term prescription generation completely.

Table 1. Demographic information about respondents.

\begin{tabular}{|c|c|c|c|c|c|c|c|c|c|}
\hline \multicolumn{10}{|c|}{ Education/Degree } \\
\hline & B.Com & B.B.A & B.Sc. & MBA & B.Pharm & M.Pharm & Others & $\begin{array}{c}\text { Total } \\
(n=100)\end{array}$ & $p$-value* \\
\hline Male & 09 & 05 & 19 & 03 & 33 & 01 & 06 & 76 & \multirow{3}{*}{5.9} \\
\hline Female & 04 & - & 04 & 01 & 13 & 02 & - & 24 & \\
\hline Total & 13 & 05 & 23 & 04 & 46 & 03 & 06 & 100 & \\
\hline \multicolumn{10}{|c|}{ Experience } \\
\hline Years & $0-1$ year & $1-2$ years & $2-3$ years & 3-4 years & 4-5 years & \multicolumn{2}{|c|}{ Above 5 years } & $\begin{array}{c}\text { Total } \\
(n=100)\end{array}$ & $p$-value* \\
\hline Male & 06 & 14 & 12 & 11 & 15 & \multicolumn{2}{|l|}{18} & 76 & \multirow{2}{*}{0.7} \\
\hline Female & 12 & 06 & 03 & 01 & 02 & - & & 24 & \\
\hline
\end{tabular}

Chi-square test was used. $* p=<0.05$ was considered significant. 
Table 2. Perception/attitude of medical representative towards basics of pharmaceutical marketing.

\begin{tabular}{lccc}
\hline Response & Strongly agree \% & Agree \% & $\begin{array}{c}\text { Strongly } \\
\text { disagree\% }\end{array}$ \\
\hline $\begin{array}{l}\text { Basics of pharmaceutical marketing knowledge is necessary for successful } \% \\
\text { detailing/increase sales volume }\end{array}$ & 81 & 14 & 5 \\
$\begin{array}{l}\text { My company provides continuous trainings directed towards } \\
\text { understanding concepts of pharmaceutical marketing strategies. }\end{array}$ & 72 & 25 & - \\
$\begin{array}{l}\text { My company provides continuous trainings directed toward marketing } \\
\text { communication and selling skills. }\end{array}$ & 67 & 30 & - \\
$\begin{array}{l}\text { My company provides continuous trainings directed towards } \\
\text { pharmaceutical product marketing and knowledge. }\end{array}$ & 64 & 28 \\
\hline
\end{tabular}

Table 3. Understanding of some basic pharmaceutical marketing terminologies/concept among medical representatives.

\begin{tabular}{|c|c|c|c|}
\hline Terminology & Understand completely \% & Understand somewhat \% & Don't understand \% \\
\hline Prescribing behavior & 88 & 12 & - \\
\hline Prescription generation & 92 & 08 & - \\
\hline Marketing mix & 64 & 32 & 04 \\
\hline Product life cycle & 60 & 32 & 08 \\
\hline Product positioning is a concept borrowed from military strategy & 48 & 20 & 32 \\
\hline Brand management & 76 & 12 & 12 \\
\hline Branded generics & 44 & 28 & 28 \\
\hline Boston matrix & 56 & 08 & 36 \\
\hline Cash-Cows & 64 & 16 & 20 \\
\hline Me-too market place & 48 & 12 & 40 \\
\hline Skimming strategy & 48 & 16 & 36 \\
\hline Penetration strategy in pricing & 52 & 24 & 24 \\
\hline Pull strategy & 44 & 44 & 12 \\
\hline Push strategy & 48 & 44 & 08 \\
\hline E-detailing & 96 & 04 & - \\
\hline Principles of medical advertising & 64 & 16 & 20 \\
\hline Pareto's law & 64 & 16 & 20 \\
\hline Blockbuster drug & 64 & 12 & 24 \\
\hline Marketing research & 48 & 24 & 28 \\
\hline Niche marketing & 44 & 16 & 40 \\
\hline Strengths weakness opportunities, threats (SWOT) analysis & 44 & 16 & 40 \\
\hline Competitive intelligence & 64 & 20 & 16 \\
\hline Pharmaeconomics & 52 & 20 & 28 \\
\hline Post-marketing surveillance & 52 & 20 & 28 \\
\hline
\end{tabular}

The respondents with Management and B Pharm degree understood completely about the marketing mix concept. They knew about product, price, place, and promotion individually but they were unaware about the term marketing mix (Kotler and Armstrong, 2010). The respondents with pharmacy background were confused with the product life cycle term, according to them product life cycle relates to product degradation, stability, and shell life. Therefore, only $60 \%$ of respondents understand completely the concept of the product life cycle. Product life cycle concept describes the products life history starting from birth to death or old age. It is also called as product span. $48 \%$ of respondents were aware of the product positioning concept which is borrowed from military strategy. The management background respondents understood the term quite well. In this concept, the importance of positioning is compared with the military strategy context. Troop disposition, ground, terrain, relative strength of opposing forces and mental attitudes of the opposition are compared with product positioning (Subba Rao, 1998).

$76 \%$ of respondents had a complete understanding regarding brand management concept. Brand management is a very important aspect of pharmaceutical marketing. Brand management is the analysis and planning on how a brand is perceived in the market. Developing a good relationship with the target market is essential for brand management (Brand Management, 2019).Only 44\% of respondents had a complete understanding regarding branded generics. They are an off-patent medicine sold under a brand name that offers something of value to patients (Why branded generics matter, 2017).

$56 \%$ of respondents understood the concept of the Boston Matrix in pharmaceutical marketing. $36 \%$ of respondents were not 
aware about the term. Boston matrix concept explains about profits (Subba Rao, 1998). As per this concept, profits are not always an appropriate indicator of portfolio analysis and performance. $64 \%$ of respondents were having complete understanding of the cash cow concept. A cash cow is a business, product line, or product that spins off a significant amount of positive cash flow (Cash Cow, 2018). Further only $48 \%$ of respondents were having complete understanding about the term Me-too market place. It takes place when a company starts a product which is just like its competitors.

$48 \%$ of respondents have a complete understanding about skimming strategy. This concept explains about pricing strategies of pharmaceutical products. Initially, the price of products will be high and gradually prices are reduced as per market requirement. $52 \%$ know about penetration strategy in pricing completely. This concept of pricing is opposite to the skimming strategy. Initially, the price of products will be less and gradually prices are increased as per market requirement (Subba Rao, 1998). 44\% of respondents understood the concept "pull strategy" completely. Some of the respondents were already practicing this strategy in their daily working but were unaware about word "pull strategy". $48 \%$ of respondents understood the concept "push strategy" completely. The push strategy got its name because it involves pushing, or urging, members of a marketing channel to sell a product by recommending it to consumers or by giving it an adequate display. Pull strategy as the name suggest aims at pulling the consumers towards the product (Subba Rao, 1998). 96\% of respondents knew about the e-detailing. It is a type of digital detailing with the help of the epad. Many pharmaceutical companies already using e-detailing concept compared to conventional detailing. Medical representatives are well versed with the latest technology in digital pharmaceutical marketing and are of opinion that the use of these technologies may help companies to stay ahead of the competition (Lad et al., 2017).

$64 \%$ had a complete understanding regarding the principles of medical advertising. In this, advertising is done to physicians and not the patients. Most of the respondents were unaware about Pareto's law. The respondents even with management background were unaware about it, $64 \%$ of respondents understand it completely. Basically, its $80-20$ rule set by the famous Italian economist Pareto. $80 \%$ of profit comes from sales of $20 \%$ of market share (Pareto Principle: How to Use It to Dramatically Grow Your Business, 2014). $64 \%$ of respondents understood completely the concept of a blockbuster drug. A blockbuster drug is an extremely popular drug that generates annual sales of at least $\$ 1$ billion for the company that sells (Chen, 2018). 48\% of respondents understood the concept of marketing research. Market research provides relevant data to help solve marketing challenges that a business will most likely face - an integral part of the business planning process. $44 \%$ of respondents understood completely what is the SWOT analysis and very few of them had a vague idea about the SWOT. It characterizes the business or project that gives it an advantage over others. $64 \%$ of respondents responded to understand completely about the competitive intelligence. It is an activity of collecting data from all possible sources and processing it into meaningful information that can be used as a strategic input for decision-making (Competitive intelligence). $52 \%$ of respondents knew about the Pharmaeconomics concept. Respondents with a pharmacy background responded understand completely. While $20 \%$ of the respondents mentioned that they understand somewhat. Pharmacoeconomics has been defined as "the description and analysis of the costs of drug therapy to healthcare systems and society." (Bhowmik et al., 2014). 52\% of respondents responded that they understand completely what is post-marketing surveillance. It is all about the phase four of clinical trial and related to pharmacovigilance system. There is a need for pharmaceutical companies to provide more resources towards equipping medical representatives with research knowledge and assure that medical representatives are able to deeply discuss scientific data and clinical trials and are able to find scientific communications that the healthcare professional find of value. (Mukattash et al., 2017).

\section{CONCLUSION}

The study indicated that the majority of medical representatives felt that the basics of pharmaceutical marketing knowledge are necessary for successful detailing. Respondents learnt some terminology about pharmaceutical marketing while working on the field and felt that it was ignored during academic's studies and training period. Overall, these findings may help pharmaceutical companies to comprehend pharmaceutical marketing concepts along with scientific knowledge in their training programs. This will lead to successful detailing and effectiveness of salesforce.

\section{CONFLICT OF INTERESTS}

Authors declare that they have no conflicts of interest.

\section{FINANCIAL SUPPORT}

None.

\section{REFERENCES}

Bhowmik D, Duraivel S, Rajalakshmi AN, Sampath Kumar KP Pharmacoeconomics - a review. Elix Pharm, 2014; 69:23672-5.

Brand management, 2019. Available via https://www. investopedia.com/terms/b/brand-management.asp (Accessed 1 May 2019). Cash Cow. 2018. Available via https://www.accountingtools com/articles/2017/5/13/cash-cow (Accessed 5 May 2019).

Chen J. Blockbuster drug (online), 2018. Available via https:// www.investopedia.com/terms/b/blockbuster-drug.asp (Accessed 5 May 2019). Competitive intelligence. Available via https://www.entrepreneur. com/encyclopedia/competitive-intelligence (Accessed 2 May 2019).

Impact of drug promotion on doctors - they become biased and do what drug-makers tell them to do, 2011. Available via http://apps.who. int/medicinedocs/en/d/Js8109e/9.html (Accessed 20 August 2004).

Kotler P, Armstrong G. Principles of marketing. Pearson Education, Inc., Prentice Hall, Upper Saddle River, NJ, 2010.

Lad P, Muragundi P, Ligade VS. Digitalize pharmaceutical marketing: medical representative perspective. Research J Pharm Tech, 2017; (7):2179-82.

Malhotra NK, Dash S. Marketing research-an applied orientation. Pearson Education, Prentice Hall, Upper Saddle River, NJ, 2010.

Mukattash T, Alattar M, Farha R. Evaluating scientific research knowledge and attitude among medical representatives in Jordan: a crosssectional survey. Curr Clin Pharmacol, 2017; (12):245-52.

Pareto principle: how to use it to dramatically grow your business, 2014. Available via https://www.forbes.com/sites/ davelavinsky/2014/01/20/pareto-principle-how-to-use-it-to-dramaticallygrow-your-business/\#73aab9f53901 (Accessed 4 May 2019).

Subba Rao SVR. Handbook of pharmaceutical marketing in India. Panther Publishers, Bangalore, India, 1998. 
The drug rep: historical background, 2007. Available via http://herbmuseum.ca/content/drug-rep-historical-backround (Accessed 4 May 2019).

Why branded generics matter, 2017. Available via https://www abbott.com/corpnewsroom/finance/why-branded-generic-matter.html (Accessed 5 May 2019).
How to cite this article:

Ligade V, Bhegade J. Evaluating pharmaceutical marketing knowledge and attitude among medical representative in Mumbai City: A quantitative study. J Appl Pharm Sci, 2020; 10(1):083-087. 